\title{
FAKTOR-FAKTOR YANG MEMPENGARUHI PEMBERDAYAAN INDUSTRI KECIL MASYARAKAT DI KECAMATAN BAKTIYA KABUPATEN ACEH UTARA \\ Hijri Juliansyah $^{* a}$, Shaleha Ulfa ${ }^{* b}$ \\ Fakultas Ekonomi dan Bisnis Universitas Malikussaleh \\ a Corresponding author:hijri.juliansyah@gmail.com \\ b shalehaulfa@gmail.com
}

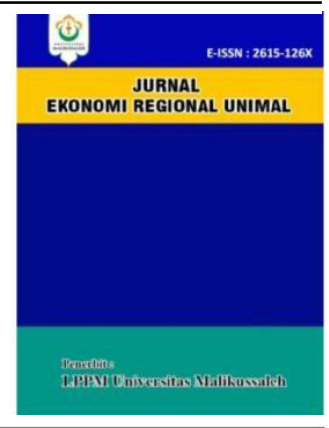

ART ICLE INFORMATION

A B S T R A C T

Keywords:

Capital, Length of Business, Number of Workers, Empowerment of Small Industries.
This study is conducted to determine the determinants of the empowerment of small industries in the Baktiya District. North Aceh Indonesia the study utilizes 61 entrepreneurs as respondens and using a multiple linear regression analysis model. The results found that capital had a significant effect on the empowerment of small industries in Baktiya District. The duration of the business did not have a significant effect on the empowerment of small industries. Labor had no significant effect on the empowerment of small industries in Baktiya District.

\section{PENDAHULUAN}

Pembangunan ekonomi merupakan serangkaian usaha yang bertujuan untuk meningkatkan taraf hidup masyarakat. Hal ini dapat didorong dengan memperluas kesempatan kerja dan pemerataan pendapatan. Proses pembangunan ekonomi sering kali dikaitkan dengan proses industrialisasi atau aktivitas industri dan pabrik. Pembangunan industri merupakan cara untuk meningkatkan kesejahteraan rakyat maupun taraf hidup yang lebih bermutu. Peran industri kecil akan semakin penting, keadaan ini akan memungkinkan sebagai alternatif yang dapat diambil adalah memasuki industri kecil dan menengah.

Industri kecil seperti pengolahan kayu limbah, kerajinan, konveksi, bunga, makanan ringan dan seterusnya di Kecamatan Baktiya Kabupaten Aceh Utara merupakan jenis industri kecil yang diharapkan menjadi pendukung perekonomian masyarakat. Berbagai keuntungan dapat dirasakan dengan munculnya industriindustri kecil ini. Selain dapat menghasilkan dan meningkatkan pendapatan bagi masyarakat, juga dapat menjadi pendukung industri Aceh.

Perkembangan industri kecil di Kecamatan Baktiya tergolong lambat, hal ini dapat diketahui dari nilai produksi hanya Rp. 530.000.000/tahun, hanya menempati urutan ke 14 dari 27 kecamatan di Aceh Utara (BPS Aceh Utara, 2016).

Tabel 1

Perkembangan Industri Kecil di Kecamatan Baktiya

\begin{tabular}{cccccc}
\hline \hline & \multicolumn{5}{c}{ Jenis Industri } \\
\cline { 2 - 6 } & Tahun & $\begin{array}{c}\text { Makanan } \\
\text { Minuman }\end{array}$ & $\begin{array}{c}\text { Barang } \\
\text { dari } \\
\text { Logam }\end{array}$ & Anyaman & Kerajinan \\
\hline & $(1)$ & $(2)$ & $(3)$ & $(4)$ & $(5)$ \\
\hline 1 & 2010 & 20 & - & 40 & - \\
2 & 2011 & 20 & - & 51 & 3 \\
3 & 2012 & 31 & 5 & 62 & 3 \\
4 & 2013 & 42 & 5 & 71 & 9 \\
5 & 2014 & 66 & 5 & 71 & 9 \\
6 & 2015 & 66 & 5 & 71 & 9 \\
\hline
\end{tabular}

Sumber : BPS Aceh Utara, 2016

Dari tabel 1 di atas dapat diketahui bahwasanya industri kecil di Kecamatan Baktiya mengalami peningkatan sejak lima tahun terakhir. Tahun 2010 hingga 2015, jumlah industri kecil yang dikelola masyarakat di Kecamatan ini masih dengan jumlah yang sama. Tidak bertambahnya usaha kecil pada tahun 2014-2015 ini disebabkan meningkatnya harga bahan baku seperti bahan bakar, meningkatnya biaya pengurusan perizinan untuk usaha serta rendahnya daya beli masyarakat. Hal ini menimbulkan problema, dimana pengelola 
usaha kecil hanya mempertahankan kuantitas dan kualitas produksi dengan ukuran yang sama seperti tahun-tahun sebelumnya, tanpa berani melakukan inovasi produk.

Pemberdayaan untuk mengembagkan industri kecil tidaklah terjadi dengan sendirinya, hal ini dapat dipengaruhi oleh berbagai faktor seperti jumlah modal, lama usaha dan tenaga kerja. Modal dalam arti ekonomi adalah hasil produksi yang digunakan untuk menghasilkan produksi selanjutnya. Semakin banyaknya jumlah modal, maka akan semakin dapat memproduksi produk, dengan demikian akan semakin meningkatnya pendapatan untuk pemberdayaan industri. Adapun dengan kata lain segala jenis barang yang dihasilkan dan dimiliki masyarakat disebut kakayaan masyarakat. Modal dalam industri kecil biasanya terdiri dari modal tetap dan modal variabel. Modal tetap digunakan oleh pengusaha untuk membeli barang-barang yang tidak habis sekali pakai atau sarana pendukung seperti rak untuk tempat dagangan, mesin dan bangunan, sedangkan modal variabel digunakan untuk membelanjakan baran $g$ dengan masa pakai relatif kecil seperti bahan baku. Berdasarkan observasi dan wawancara awal dengan pelaku industri kecil di Baktiya yang melakukan aktivitas rutin ini untuk menghasilkan produk dengan kualitas dan kuantitas yang diinginkan. Namun, sebagian pelaku usaha memiliki keterbatasan modal untuk mengembangkan industri dan memperluas pasar

Lama usaha menentukan pengalaman berusaha. Lamanya seorang pelaku bisnis menekuni bidang usahanya akan mempengaruhi kemampuan profesionalnya untuk mencapai keberdayaan atau pendapatan sesuai dengan target. Semakin lama menekuni bidang usaha perdagangan akan makin meningkatkan pengetahuan tentang selera ataupun perilaku konsumen. Secara teoritis, semakin lama usaha, maka semakin mahir pelaku usaha menguasai proses produksi dan proses pemasaran, maka akan semakin meningkatnya, dengan meningkatnya kuantitas produksi, maka akan semakin tinggi pendapatan yang dapat memberdayakan industri kecil. Faktor lama usaha juga ikut menentukan pemberdayaan industri kecil di Kecamatan Baktiya.
Selanjutnya jumlah tenaga kerja berperan besar menentukan pemberdayaan industri kecil dan menengah, hal ini dikarenakan jumlah tenaga kerja yang berkualitas dapat menghasilkan produk industri kecil yang berkualitas juga. Secara teori, semakin banyaknya jumlah tenaga kerja, maka akan semakin tinggi tingkat produksi. Semakin tingginya produktivitas maka akan semakin meningkatkan. Namun, banyak tenaga kerja yang dipekerjakan pada industri kecil di Kecamatan Baktiya cenderung menurun, hal ini mengindikasikan ketidakstabilan usaha.

Berdasarkan uraian masalah keterbatasan modal kerja, lama usaha namun tidak menunjukkan peningkatan produksi dan pendapatan pengusaha industri kecil di Kecamatan Baktiya dan rendahnya produktivitas tenaga kerja dalam jumlah yang tinggi, maka penulis hendak melakukan penelitian yang berjudul" FaktorFaktor Yang Mempengaruhi Pemberdayaan Industri Kecil Masyarakat Di Kecamatan Baktiya Kabupaten Aceh Utara"

Tujuan penelitian ini adalah untuk mengetahui:

1. Seberapa besar pengaruh jumlah modal terhadap pemberdayaan industri kecil di Kecamatan Baktiya Kabupaten Aceh Utara.

2. Seberapa besar pengaruh lama usaha terhadap pemberdayaan industri kecil di Kecamatan Baktiya Kabupaten Aceh Utara.

3. Seberapa besar pengaruh jumlah tenaga kerja terhadap pemberdayaan industri kecil di Kecamatan Baktiya Kabupaten Aceh Utara.

\section{METODE PENELITIAN Lokasi dan Objek Penelitian}

Objek penelitian ini adalah pemberdayaan industri kecil (pendapatan yang diterima), jumlah modal usaha (modal awal) yang dimiliki industri kecil, lama usaha (pengalaman usaha) dan jumlah tenaga kerja yang dipekerjakan pada industri kecil. Penelitian ini dilakukan di Kecamatan Baktiya Kabupaten Aceh Utara. 


\section{Populasi dan Sampel Penelitian}

\section{Populasi}

Populasi adalah keseluruhan subyek penelitian(Arikunto, 2006).Yang menjadi populasi dalam penelitian ini adalah industri kecil di Kecamatan Baktiya yang terdata menurut BPS Aceh Utara Tahun 2016 yakni sebanyak 151 unit dengan 151 pemilik(BPS Aceh Utara, 2016).

\section{Sampel}

Teknik pengambilan sampel yang digunakan adalah dengan purposive sampling. Menurut (Jogiyanto, 2004)“Purposive sampling adalah teknik pengambilan sampel berdasarkan suatu kriteria tertentu seperti usia usaha lebih dari satu tahun.

Menurut(Suharso, 2009) untuk menentukan ukuran sampel dari suatu populasi, dapat digunakan rumus Slovin sebagai berikut:

$n=\frac{N}{1+N e^{2}}$

Ket:

$$
\begin{array}{ll}
\mathrm{N} & : \text { Jumlah sampel } \\
N & : \text { Populasi } \\
\mathrm{e} & : \text { Margin error } \\
1 & : \text { bilangan Konstan }
\end{array}
$$

Sesuai dengan populasi sebanyak 151 orang dengan presisinya sebesar $10 \% \quad(0,1)$. Sehingga hasil yang didapat dengan rumus tersebut adalah sebagai berikut.

$$
n=\frac{N}{1+151(0,1)^{2}}
$$

$N=\frac{151}{1+151(0.1)^{2}}=60,51$ (dibulatkan menjadi 61).

Berdasarkan rumus di atas, maka diperoleh jumlah sampel terpilih sebanyak 61 orang.

\section{Definisi Operasional Variabel}

Untuk memperjelas dan mempermudah pemahaman terhadap variabel-variabel yang akan dianalisis dalam penelitian ini, maka dapat dijelaskan sebagai berikut:

1. Jumlah modal (X1)

Jumlah uang yang dikeluarkan untuk membiayai proses produksi dalam kegiatan industri kecil yang keseluruhannya merupakan biaya produksi, diukur dalam satuan Rupiah (Rp).
2. Lama usaha (X2)

Jangka waktu yang telah digunakan untuk mengelola industri kecil, diukur dalam satuan Tahun

3. Jumlah tenaga kerja (X3)

Banyaknya orang yang dipekerjakan pada industri kecil, diukur dalam satuan Orang

4. Pemberdayaan industri kecil (Y)

Banyaknya pendapatan yang diterima industri kecil, diukur dalam satuan Rupiah (Rp).

\section{Uji Asumsi Klasik \\ Uji Normalitas}

Uji normalitas bertujuan untuk menguji apakah dalam model regresi, variabel terikat (dependent) dan variabel bebas (independent) residualnya terdistribusi normal atau tidak. Salah satu metode yang banyak digunakan untuk menguji normalitas adalah dengan uji Jarque-Bera.

\section{Uji Heteroskedastisitas}

Heterokedastisitas adalah situasi penyebaran data yang tidak sama atau tidak samanya variansi sehingga uji siginifikansi tidak valid. Untuk mendeteksi heteroskedastisitas menggunakan White's General Heteroscedasticity test(Gujarati, 2003).

\section{Uji Multikolinearlitas}

uji multikolinieritas adalah suatu kondisi dimana terjadi korelasi yang kuat diantara variable bebas (independen) yang diikut sertakan dalam pembentukan model regresi.Untuk menguji masalah multikolinearitas dapat melihat matriks korelasi dengan meregresi variabel $\mathrm{X}_{1}$ dan $\mathrm{X}_{2}$, jika terjadi koefisien korelasi lebih dari 0,80 maka terdapat multikolinearitas(Gujarati, 2003).

\section{Teknik Analisis Data}

Data-data penelitian yang terkumpul kemudian dianalisis dengan menggunakan analis regresi linear berganda dengan menggunakan rumus

$$
Y=a+\beta_{1} X_{1}+\beta_{2} X_{2}+\beta_{3} X_{3}+e
$$

Dimana :

$\mathrm{Y}=$ Pemberdayaan Industri Kecil

$\mathrm{X}_{1} \quad=$ Jumlah Modal 


$$
\begin{array}{ll}
\mathrm{X}_{2} & =\text { Lama usaha } \\
\mathrm{X}_{3} & =\text { Jumlah tenaga kerja } \\
\mathrm{a} & =\text { Konstanta } \\
\beta & =\text { Koefesien yang dicari } \\
\mathrm{e} & =\text { standar error }
\end{array}
$$

Dikarenakan variabel-variabel yang digunakan tidak memiliki satuan yang sama, maka diubah dalam bentuk logaritma (Log). Adapun rumus analisis data adalah sebagai berikut:

$\log Y=a+\log b_{1} X_{1}+\log b_{2} X_{2}+\log$ $\mathrm{b}_{2} \mathrm{X}_{2}+\mathrm{ei}$

\section{Pengujian Hipotesis}

\section{Uji T}

Uji t dilakikan bertujuan ntuk mengetahui pengaruh variabel bebas secara parsial atau individu terhadap variabel tidak bebas dengan asumsi variabel yang lain konstan.

1. Apabila $t_{\text {hitung }}<\mathrm{t}_{\text {tabel }}$ atau nilai probabilitas (sig) $>0,05$, maka Ho diterima dan Ha ditolak. Artinya tidak terdapat pengaruh variabel independen terhadap variabel dependen.

2. Apabila $t_{\text {hitung }}>t_{\text {tabel }}$ atau nilai probabilitas (sig) $<0,05$, maka Ho ditolak dan Ha diterima. Artinya terdapat pengaruh variabel independen terhadap variabel dependen.

\section{Uji F}

Uji Simultan (Uji F-statistik) digunakan untuk menguji besarnya pengaruh dari seluruh variabel independent tehadap variabel dependent.

1. Jika Fhitung < Ftabel, maka $\mathrm{H}_{\mathrm{a}}$ diterima artinya secara statistik dapat dibuktikan bahwa variabel independent tidak berpengaruh terhadap variabel dependent.

2. Jika Fhitung $>$ Ftabel, maka $\mathrm{H}_{\mathrm{a}}$ diterima artinya secara statistik dapat dibuktikan bahwa variabel independent berpengaruh terhadap variabel dependent.

\section{Koefisien Korelasi $(\mathbf{R})$ dan Determinasi $\left(\mathbf{R}^{\mathbf{2}}\right)$}

Koefisien korelasi adalah pengukuran statistik kovarian atau asosiasi antara dua variabel.Koefisien korelasi menunjukkan kekuatan (strength) hubungan linear dan arah hubungan dua variabel acak.Sedangkan koefisien determinasi $\left(\mathrm{R}^{2}\right)$ digunakan untuk menunjukkan seberapa besar persentase variasi variabel independen dapat menjelaskan variasi variabel dependennya.

\section{HASIL PENELITIAN DAN PEMBAHASAN}

\section{Analisis Deskriptif Variabel}

\begin{tabular}{|c|c|c|c|c|}
\hline & \multicolumn{4}{|c|}{$\begin{array}{c}\text { Tabel 2 } \\
\text { Deskripsi Variabel Penelitian }\end{array}$} \\
\hline & $\mathrm{X}_{1}$ & $\mathrm{X}_{2}$ & $\mathrm{X}_{3}$ & $\mathrm{Y}$ \\
\hline Mean & 8375902 . & 4.491803 & 1.655738 & 22925738 \\
\hline Median & 2500000 . & 3.000000 & 1.000000 & 3500000 . \\
\hline Maximum & $1.30 \mathrm{E}+08$ & 17.00000 & 4.000000 & $8.20 \mathrm{E}+08$ \\
\hline Minimum & 60000.00 & 1.000000 & 1.000000 & 300000.0 \\
\hline Std. Dev. & 19178283 & 3.294556 & 0.814151 & $1.05 E+08$ \\
\hline Observation & 61 & 61 & 61 & 61 \\
\hline
\end{tabular}

Berdasarkan data dari hasil penelitian dapat dilihat deskripsi pengaruh modal, lama usaha dan jumlah tenaga kerja terhadap pemberdayaan industri kecil sebagai berikut:

Berdasarkan Tabel 2 di atas dapat dilihat bahwa rata-rata jumlah modal yang dikeluarkan oleh pengusaha industri kecil di Kecamatan Baktiya adalah adalah Rp.8.375.902, lama usaha rata-rata adalah 4,49 tahun, jumlah tenaga kerja yang digunakan rata-rata sebanyak 1,65 orang dan pendapatan rata-rata per bulan Rp. 22.925.738.

\section{Uji Asumsi Klasik}

\section{Uji Normalitas}

Menurut(Ghozali, 2012)uji normalitas bertujuan untuk menguji apakah dalam model regresi, variabel penggangu atau residual memiliki distribusi normal. Penelitian ini menggunakan metode Jarque-Bera (J-B) Test untuk mengetahui normal atau tidak normalnya model regresi, variabel peganggu atau residual. Dengan cara membandingkan nilai J-B hitung dengan nilai $\mathrm{X}^{2}$ (Chi-Square) table.

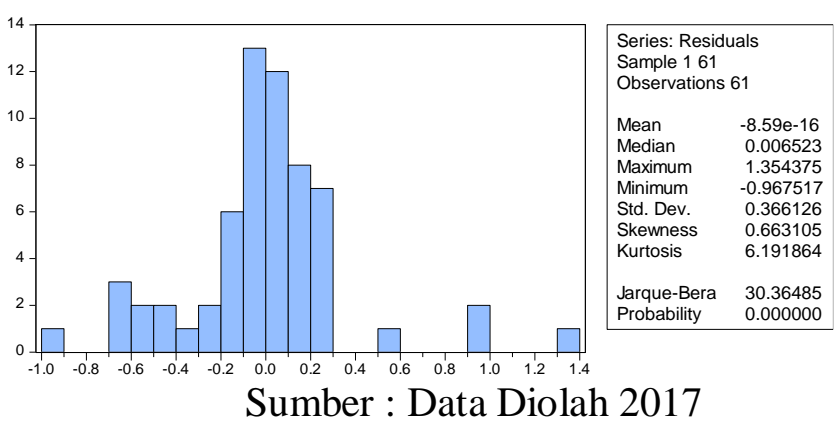

Gambar 1 Hasil Uji Normalitas 
Untuk mengetahui normal atau tidak normalnya model regresi, variabel peganggu atau residual. Dengan cara membandingkan nilai J-B hitung dengan nilai (Chi-Square) tabel. Nilai tabel dengan $\mathrm{df}=61-4=57$. Jika dibandingkan dengan nilai Jarque-Bera pada gambar di atas sebesar 30.36485, maka dapat disimpulkan bahwa model regresi, variabel peganggu atau residual terdistribusi normal karena nilai Jarque-Bera > nilai tabel atau $30.36485<75.623$.

\section{Uji Multikolinieritas}

Multikolonieritas adalah adanya hubungan linier yang signifikan antara beberapa atau semua variable independent dalam model regresi. Jika terdapat Multikolinieritas maka koefisien regresi menjadi tidak tentu, tingkat kesalahannya menjadi sangat besar dan biasanya ditandai dengan nilai koefisien determinan yang sangat besar tetapi pada pengujian parsial koefisien regresi, tidak ada ataupun kalau ada sangat sedikit sekali koefisien regresi yang signifikan.

Tabel 3 Hasil Uji Multikolinearitas

\begin{tabular}{ccccc}
\hline & $\mathrm{Y}$ & $\mathrm{X} 1$ & $\mathrm{X} 2$ & $\mathrm{X} 3$ \\
\hline $\mathrm{Y}$ & 1 & 0.254 & -0.120 & 0.268 \\
$\mathrm{X} 1$ & 0.254 & 1 & 0.034 & 0.495 \\
$\mathrm{X} 2$ & -0.1208 & 0.034 & 1 & -0.190 \\
$\mathrm{X} 3$ & 0.268 & 0.495 & -0.190 & 1 \\
\hline
\end{tabular}

Sumber : Data Eviews (Data Diolah)

Pada tabel diatas menunjukkan bahwa dalam model regresi tidak terjadi multikolinearitas. Hal ini dibuktikan dengan nilai korelasi tersebut di atas lebih kecil dari 0,8

\section{Uji Heteroskedastisitas}

Suatu penelitian dikatakan memiliki masalah heteroskedastisitas apabila nilai error atau residual model yang diamati tidak memiliki varian yang konstan dati satu observasi ke observasi yang lainnya. Hasil uji heteroskedastisitas berdasarkan uji White dapat dilihat pada tabel berikut :

Tabel 4

Hasil Uji Heteroskedastisitas

Heteroskedasticity Test: White

\begin{tabular}{llll}
\hline \hline F-statistic & 1.651233 & Prob. F(9,51) & 0.1258 \\
Obs*R-squared & 13.76422 & Prob. Chi-Square(9) & 0.1310 \\
Scaled explained SS & 295.6473 & Prob. Chi-Square(9) & 0.0000 \\
\hline & & & \\
\hline \hline
\end{tabular}

Sumber : Data Diolah 2017
Berdasarkan tabel diatas dapat kita lihat bahwa nilai probabilitas Obs*R-square sebesar 13.76422 dibandingkan dengan tingkat signifikansi (alpha) sebesar 0.1310. Jika nilai probabilitas signifikansinya di atas 0,05 maka dapat disimpulkan tidak terjadi heteroskedastisitas.

\section{Pembahasan}

\section{Analisis Regresi Linier Berganda}

Untuk mengetahui hasil penelitian ini dapat dilihat dari output regresi linear berganda pada tabel 5 berikut ini :

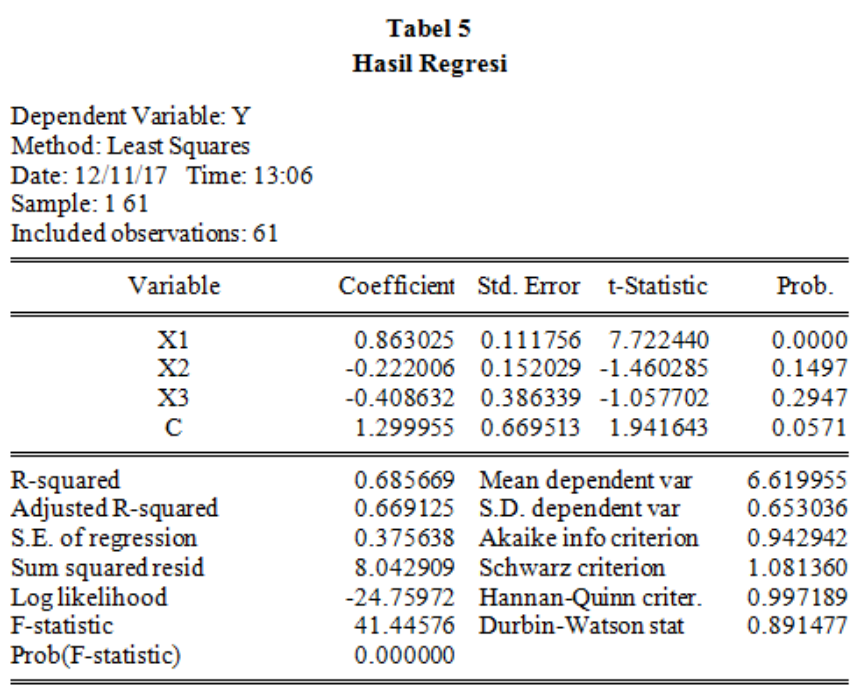

Sumber: Data Diolah, 2017

Berdasarkan data dari table 5 diatas dapat dibuat persamaan regresi linear berganda sebagai berikut

$\mathrm{Y}=1.295+0.865 \mathrm{X}_{1}-0.22 \mathrm{X}_{2}-0.41 \mathrm{X}_{3}$

Dari formulasi model di atas menunjukkan bahwa nilai variabel konstanta sebesar 1.299955 yang berarti bahwa jika jika modal, lama usaha dan tenaga kerja nilainya 0 , maka pendapatan industri kecil di Kecamatan Baktiya sebesar 1.29.

Nilai koefisien dari dari variabel modaladalah sebesar 0.865 , yang berarti apabila modal meningkat $1 \%$, maka akan meningkatkan pendapatan industri kecil di Kecamatan Baktiya sebesar $0,86 \%$.

Nilai koefesien dari variabel lama usaha adalah sebesar -0.22 yang berarti apabila lama usaha meningkat $1 \%$, maka akan menurunkan pendapatan industri kecil di Kecamatan Baktiya sebesar $0,22 \%$

Nilai koefisien dari dari variabel tenaga kerja adalah sebesar -0.4 , yang berarti apabila tenaga kerja bertambah $1 \%$, maka akan 
menurunkan pendapatan industri kecil di Kecamatan Baktiya sebesar 0,41\%.

\section{Pengujian Hipotesis}

\section{Uji T (Uji Parsial)}

1. Membandingkan nilai $\mathrm{t}$ hitung dalam tabel coefficients dengan $\mathrm{t}$ tabel. Jika $\mathrm{t}$ hitung $>\mathrm{t}$ tabel maka $\mathrm{H}_{1} \mathrm{H}_{2}$ dan $\mathrm{H}_{3}$ diterima artinya terdapat pengaruh secara parsial antara variabel independen terhadap variabel dependen.Jika $\mathrm{t}$ hitung $<\mathrm{t}$ tabel maka $\mathrm{H}_{1} \mathrm{H}_{2}$ dan $\mathrm{H}_{3}$ ditolak artinya tidak terdapat pengaruh secara parsial antara variabel independen terhadap variabel dependen.

2. Berdasarkan nilai probabilitas. Jika nilai signifikansi lebih kecil dari 0,05 atau 5\% maka hipotesis yang diajukan diterima atau dikatakan signifikan. Jika nilai signifikansi lebih besar dari 0,05 atau 5\% maka hipotesis yang diajukan ditolak atau dikatakan tidak signifikan.

\begin{tabular}{crrrr}
\multicolumn{5}{c}{ Tabel 6 } \\
Hasil Uji Parsial & & \\
\hline \hline Variable & Coefficient & Std. Error & t-Statistic & Prob. \\
\hline \hline X1 & 0.863025 & 0.111756 & 7.722440 & 0.0000 \\
X2 & -0.222006 & 0.152029 & -1.460285 & 0.1497 \\
X3 & -0.408632 & 0.386339 & -1.057702 & 0.2947 \\
C & 1.299955 & 0.669513 & 1.941643 & 0.0571 \\
\hline \hline
\end{tabular}

Dari hasil tabel 6 maka perhitungan uji secara parsial diperoleh nilai $\mathrm{t}$ hitung sebesar7.722440 dengan signifikansi 0.0000 , serta $t$ tabel sebesar 2.002. Karena nilai signifikansi lebihkecil daripada 0,05 dan nilai $t$ hitung lebih besar dari pada $\mathrm{t}$ tabel maka dapat disimpulkan bahwa modal berpengaruh signifikan terhadap pemberdayaan industri kecil di Kecamatan Baktiya, sehingga hipotesis yang diajukan diterima kebenarannya.

Dari hasil perhitungan uji secara parsial diperoleh nilai $\mathrm{t}$ hitung sebesar-1.460285 dengan signifikansi 0.1497 , serta $\mathrm{t}$ tabel sebesar 2.002. Karena nilai signifikansi lebih besar daripada 0,05 dan nilai $t$ hitung lebih kecil dari pada $t$ tabel maka dapat disimpulkan bahwa lama usaha tidak berpengaruh signifikan terhadap pemberdayaan industri kecil di Kecamatan Baktiya, sehingga hipotesis yang diajukan ditolak kebenarannya.
Dari hasil perhitungan uji secara parsial diperoleh nilai $\mathrm{t}$ hitung sebesar-1.057702 dengan signifikansi 0.2947, serta $t$ tabel sebesar 2.002. Karena nilai signifikansi lebih besar daripada 0,05 dan nilai $\mathrm{t}$ hitung lebih kecil dari pada $\mathrm{t}$ tabel maka dapat disimpulkan bahwa tenaga kerja tidak berpengaruh signifikan terhadap pemberdayaan industri kecil di Kecamatan Baktiya, sehingga hipotesis yang diajukan ditolak kebenarannya.

\section{Uji F (Uji Serempak)}

Uji F dilakukan untuk melihat pengaruh variabel - variabel independen secara keseluruhan terhadap variabel dependen. Pengujian dilakukan dengan membandingkan nilai $F_{\text {hitung }}$ dengan $F_{\text {tabel }}$ .(Sulaiman, 2004).Untuk menguji pengaruh simultan tersebut dapat dilakukan dengan dua cara sebagai berikut :

1. Membandingkan nilai $\mathrm{F}$ hitung dalam tabel ANOVA dengan $\mathrm{F}$ tabel. Jika $\mathrm{F}$ hitung $>\mathrm{F}$ tabel maka hipotesis yang diajukan diterima artinya terdapat pengaruh secara bersama-sama antara variabel independen terhadap variabel dependen. Jika $F$ hitung $<F$ tabel maka hipotesis ditolak artinya tidak terdapat pengaruh secara bersama-sama antara variabel independen terhadap variabel dependen.

2. Berdasarkan nilai probabilitas. Jika nilai signifikansi lebih kecil dari 0,05 atau 5\% maka hipotesis yang diajukan diterima atau dikatakan signifikan. Jika nilai signifikansi lebih besar dari 0,05 atau 5\% maka hipotesis yang diajukan ditolak atau dikatakan tidak signifikan.

$$
\begin{gathered}
\text { Tabel } 7 \\
\text { Hasil Uji-F }
\end{gathered}
$$

\begin{tabular}{lrlrc}
\hline \hline \multicolumn{1}{r}{ Variable } & Coefficient & Std. Error & t-Statistic & Prob. \\
\hline \hline \multicolumn{1}{c}{ X1 } & 0.863025 & 0.111756 & 7.722440 & 0.0000 \\
X2 & -0.222006 & 0.152029 & -1.460285 & 0.1497 \\
X3 & -0.408632 & 0.386339 & -1.057702 & 0.2947 \\
C & 1.299955 & 0.669513 & 1.941643 & 0.0571 \\
\hline \hline R-squared & 0.685669 & Mean dependent var & 6.619955 \\
Adjusted R-squared & 0.669125 & S.D. dependent var & 0.653036 \\
S.E. of regression & 0.375638 & Akaike info criterion & 0.942942 \\
Sum squared resid & 8.042909 & Schwarz criterion & 1.081360 \\
Log likelihood & -24.75972 & Hannan-Quinn criter. & 0.997189 \\
F-statistic & 41.44576 & Durbin-Watson stat & 0.891477 \\
Prob(F-statistic) & 0.000000 & & & \\
\hline \hline
\end{tabular}

Sumber : Data Diolah, 2017 
Berdasarkan Tabel 7 di atas dapat dilihat bahwa hasil uji $\mathrm{F}$ menunjukkan nilai $\mathrm{F}$ hitung sebesar 41.44576 dengan signifikansi sebesar 0,0000. Nilai signifikansi tersebut lebih kecil daripada 0.05 sehingga dapat disimpulkan bahwa variabel independen yaitu modal, lama usaha dan tenaga kerja secara simultan berpengaruh sangat signifikan terhadap pemberdayaan industri kecilsehingga hipotesis yang diajukan diterima.

\section{Analisis Determinasi $\left(\mathbf{R}^{2}\right)$}

\begin{tabular}{lrll}
\multicolumn{4}{c}{ Tabel S } \\
Hasil Analisis Determinasi \\
\hline \hline R-squared & 0.685669 & Mean dependent var & 6.619955 \\
Adjusted R-squared & 0.669125 & S.D. dependent var & 0.653036 \\
S.E. of regression & 0.375638 & Akaike info criterion & 0.942942 \\
Sum squared resid & 8.042909 & Schwarz criterion & 1.081360 \\
Log likelihood & -24.75972 & Hannan-Quinn criter. & 0.997189 \\
F-statistic & 41.44576 & Durbin-Watson stat & 0.891477 \\
Prob(F-statistic) & 0.000000 & & \\
\hline \hline
\end{tabular}

Sumber: Data Diolah, 2017

Nilai $R$ Square $\left(\mathrm{R}^{2}\right)$ pada tabel 8 di atas sebesar 0.669125atau 66,92\%. Artinya variabel independen yaitu modal, lama usaha dan tenaga kerja dapat menerangkan variabel dependen yaitu pemberdayaan sebesar $66,92 \%$, sedangkan sisanya sebesar 33,08\% diterangkan oleh variabel-variabel lain yang tidak di masukkan dalam model regresi pada penelitian ini.

\section{PENUTUP}

\section{Kesimpulan}

Berdasarkan analisis data dan pembahasan hasil penelitian, dapat ditarik kesimpulan sebagai berikut:

1. Modal berpengaruh signifikan terhadap pemberdayaan industri kecil di Kecamatan Baktiya.

2. Lama usaha tidak berpengaruh signifikan terhadap pemberdayaan industri kecil di Kecamatan Baktiya.

3. Tenaga kerja tidak berpengaruh signifikan terhadap pemberdayaan industri kecil di Kecamatan Baktiya.

\section{Saran}

Berdasarkan beberapa kesimpulan di atas, maka saran yang dapat diberikan melalui hasil penelitian ini sebagai berikut:
1. Kepada Pemerintah Aceh Utara, perlu melakukan pembinaan usaha industri kecil untuk melihat masih terjadinya ketidakberdayaan industri kecil di Aceh Utara.

2. Pengusaha sebaiknya lebih memperkirakan modal yang dikeluarkan dan pembukaan akses pasar yang lebih baik, agar usaha yang dijalankan berkelanjutan.

3. Penelitian selanjutnya meneliti dengan menggunakan variabel yang lebih mendalam agar ditemukan hasil penelitian yang lebih signifikan.

\section{KEPUSTAKAAN}

Arikunto, Suharsimi. 2006. "Prosedur Penelitian Suatu Pendekatan Praktik." Jakarta: Penerbit Lembaga FEUI.

Ariyanti. 2013. "Peran Desain Interior Terhadap Kepuasan Pemustaka." 3(11): 1868-73.

Asmie, Poniwati. 2008. "Analisis Faktor-Faktor Yang Mempengaruhi Tingkat. Pendapatan Pedagang Pasar Tradisional Di Kota Yogyakarta." : 45-57.

Boediono, and Koster A. 2004. "Teori Dan Aplikasi : Statistik Dan Probabilitas." Bandung: Remaja Rosdakarya.

BPS. 2016. “Aceh Utara Dalam Angka.” BPS: Lhoksukon.

Brigham, Eugene F, and Houston. 2006. "Fundamental of

FinancialManagement: Dasar-Dasar Manajemen

Keuangan.Edisi

Kesepuluh." Jakarta: Salemba Empat.

Ghozali, Imam. 2012. "Aplikasi Analisis Multivariate Dengan Program Eviews." UNDIP: Semarang.

Gujarati, Damodar. 2003. "Ekonometrika Dasar." Jakarta: Penerbit Erlangga.

Jogiyanto. 2004. "Metodologi Penelitian Bisnis." Yogyakarta: BPFE.

Nazir, Moh. 2003. "Metode Penelitian. Cetakan Kelima." Jakarta: Penerbit Ghalia Indonesia.

Soedrajat. 2000. "Beberapa Catatan Tentang Permasalahan Pinjaman Komersil Luar Negeri." Jakarta: Usakti-Press.

Suharso. 2009. "Berita TerkiniMetode Penelitian Kuantitatif Untuk Bisnis: Pendekatan Filosofi Dan Praktis, Cetakan Pertama." Jakarta: Penerbit Indeks. 
Sukirno, Sadono. 2006. "Makro Ekonomi Teori

Pengantar (Edisi Ke-3)." Jakarta: PT.

Raja Grafindo Persada.

Sulaiman, Wahid. 2004. "Analisis-Analisis

Regresi Menggunakan SPSS."

Yogyakarta: ANDI.

Tambunan, Tulus. 2002. "Usaha Kecil Dan

Menengah Di Indonesia Beberapa Isu

Penting." Jakarta: Salemba Empat. 